\title{
Digital Economy: Problems and Prospects of Development in Ukraine
}

\author{
Ludmila Boyko, Nataliia Bieliaieva, Sergiy Bay
}

\begin{abstract}
This paper aims to analyze the challenges and opportunities that are facing developing countries in the process of creating the digital economy. Digital economy is characterized by high added value, faced with numerous obstacles, many developing countries cannot adequately respond to the demands of the digital economy. The digital economy is also referred to as the Internet Economy, New Economy, or Web Economy. The largest players in the world market are digital economy companies Apple, Google, Microsoft, Amazon and others, which are among the most expensive companies in the world in terms of market capitalization. The Fourth Industrial Revolution is rapidly driving transformational disruption across every sector. An estimated $70 \%$ of new value created in the economy over the next decade will be based on digitally enabled platforms. Digital technologies should be a driving force for innovations in the Ukrainian economic system. Digitalization of the economy and life spheres will create new jobs, make Ukrainian business more competitive and less resource oriented, attract new investors. Digital transformation is a daunting task. Countries that have reached the highest level of digital maturity have had to deal with complex cultural, organizational, and technical issues, and only counting of all these factors have made these transformations successful. The widespread use of digital technologies, extensive digital infrastructures are contributing to the economy digitization.
\end{abstract}

Keywords: digital economy, digital society, information and communication technologies development, information society

\section{INTRODUCTION}

In the conditions of globalization, the active introduction of the latest information and communication technologies in different spheres of life is a necessary and justified process. This process provides better services for the population, reduced budget expenditures while improving the quality of services, upgrading transport infrastructure, energy, supporting small and medium-sized businesses, reforming the social sphere of city life, improving the quality of health, education and environmental problems solving. All these positive changes contribute to the sustainable development of society and the state as a whole.

The emergence of a new digital infrastructure, including wireless networks, mobile devices and technologies, contributes to a radical shift in information technologies, their integration into all manifestations of socio-political and economic life of society, the formation of a new theoretical concept of industrial society - information society. As

Revised Version Manuscript Received on October 15, 2019.

Ludmila Boyko, Department of Public Management and Administration, Kyiv National University of Trade and Economics, Kiyv, Ukraine. Email: lyudmilapresident@gmail.com

Nataliia Bieliaieva*, Department of Management, Kyiv National University of Trade and Economics, Kiyv, Ukraine. Email: n.bieliaieva@knute.edu.ua

Sergiy Bay, Department of Management, Kyiv National University of Trade and Economics, Kiyv, Ukraine. Email: s.bay @knute.edu.ua modern information and communication technologies work with information in digital form, so usually it is used the term "digital society" (as a synonymous) when we talk about such a category as an "information society".

A digital society is a society created as a result of industrial revolution on the basis of information and telecommunication technologies and information that embraces people's knowledge. Digital society is socially transformed and aimed to help individuals and communities to use knowledge and ideas that help people to realize their potential and fulfill their aspirations, add a great opportunities to human intelligence, and create resources that change the way of social work and social life. The economy of such a society is called a digital economy [1].

\section{RESEARCH CONCEPT}

The term "digital economy" was defined in 1995 by Donald Tapscott, and its concept was formulated by the American programmer Nicholas Negroponte - in the narrow sense as "the transition from atom processing to bit processing" [2].

S. Veretyuk notes that the digital economy is an integral part of an economy, in which individual knowledge and intangible production are dominated - and that is a key indicator in defining the information society. The concepts of "digital economy", "knowledge economy", "information society" form a new economic system that replaces the industrial paradigm. This economic model enables the implementation of highly competitive products with a high value-added, the creation of a new quality jobs, the search of effective solutions to social, cultural and environmental problems. Developed countries pay great attention to the harmonious development of system-building elements of the digital economy, the information society and the knowledge economy [3].

Instead, S. Kolyadenko views the digital economy as being based on the production of electronic goods and services by a high-tech business entities and the distribution of these products through e-commerce. That is, by a digital economy, the author understands the production, sales and supply of products via computer networks [4].

So, that sounds like true that the "digital economy" is the basis of the strategy of the future [5].

Therefore, the digital economy is an economy based on digital computer technologies.

Published By: 


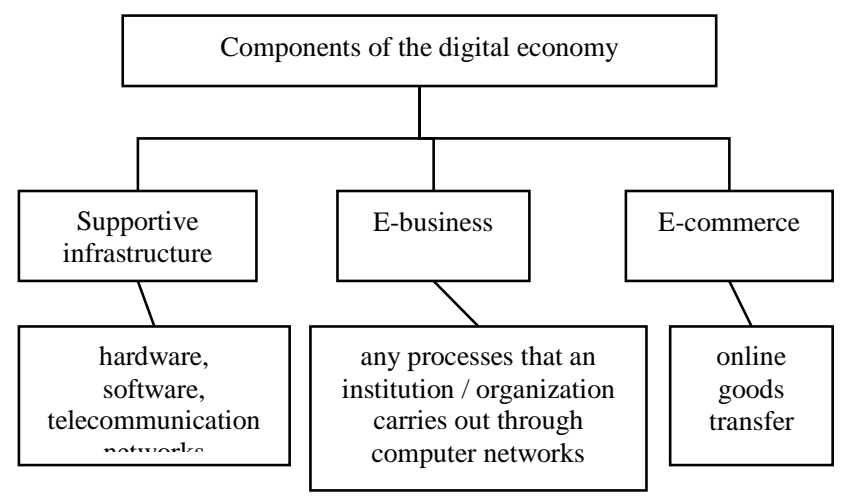

Fig. 1: Components of the digital economy (formed by the author on the basis of [6])

The development of the digital economy in most developed countries, such as the United States, Canada, Japan, Germany, is a strategic goal for the coming decades. Digital technologies should also be a driving force for innovations in the Ukrainian economic system. The digital economy is the most important engine of innovations, competitiveness and economic development in the country [7].

Given the current level of information and communication technologies development, it is worth noting the emergence of a new models of doing business, the formation of network structures based on collective methods of production and consumption, that in some way transform the classic market relations in the direction of the constant need to produce new solutions in the field of technologies creation and management. In this context, more and more countries are striving for the digital economy development, taking its advantages to tackle the key problems of socio-economic development: environmental degradation, as well as unemployment, poverty, as the development of digital infrastructure will guarantee new job creation in innovative areas.

It is important to understand that the digital economy is not a separate industry, but a virtual environment that complements our reality. Increasingly, the digital economy is intertwined with the traditional economy, making the process of theirs clear delineation more difficult. The main products of the digital economy are the same traditional economy goods and services but provided by computer equipment and digital systems, such as the Internet. This has its advantages, most important of which is the increasing of ordinary users' accessibility (and not just large companies) to certain markets (goods or services), reducing transaction costs, increasing efficiency and competitiveness [8].

Today's national digital strategies provide to take into account various issues of economic development - ensuring sustainable socio-economic development, increasing employment, forming an effective public sector, gaining new competitive advantages, creating and supporting innovative projects and companies. It is important to note that today, the largest players in the world market are digital economy companies - Apple, Google, Microsoft, Amazon and others, which are among the most expensive companies in the world in terms of market capitalization [9].

Nowadays the digital economy dictates that market leaders are determined not by many years of success story, not by the

value of real estate and assets, not by the number of patents or access to capital, but by the ability to change and adapt their business to new conditions. The digital technologies emerging over the last decade help to find sources of efficiency increasing and opportunities for rapid competitive development of enterprises. At the same time, they require to change existing management models, to reformate communications, technologies and organizational structure of the enterprises on the base on new values, priorities and benchmarks. And the latter should be based on partnership, customer orientation, innovation and synergy.

So nowadays, enterprises need to use not one but a whole set of integrated digital technologies, products and services (BioTech, NanoTech, RetailTech, FinTechLegalTech, InsurTech, GovTech, BlockChain, Digital marketing, CRM \& BPM on bpm'online platform, Grid technology, Digital insurance, ePrescription, TeleHealth). All of them have a certain value for business - they accelerate work, save resources, increase profits, create unique user experience, open up fundamentally new branches of development [10].

\section{MAIN RESULTS}

In Ukraine, digitalisation of the economy is one of the priority areas of development due to the availability of humans intellectual potential.

Successful digital economy requires effective legislative regulation. On January 17, 2018, the Cabinet of Ministers of Ukraine approved the decree "About acceptance the concept of development of the digital economy and society of Ukraine for 2018-2020 and approving a plan of measures for its implementation". The plan contains 31 comprehensive tasks, including such innovative as: the development of Industry 4.0, digital jobs, STEM education and digital education services, digital infrastructure for the Internet of Things, blockchain, e-Health and e-security, etc. Digitalization of the economy and life spheres will create new jobs, make Ukrainian business more competitive and less resource oriented, attract new investors [11].

The main purpose of the Concept is to implement the accelerated scenario of digital development as the most relevant for Ukraine in terms of challenges, needs and opportunities. An accelerated digital development scenario involves:

- removing legislative, institutional, fiscal and other obstacles that hinder the development of the digital economy;

- introducing incentives and motivations to encourage business and the economy as a whole to digitize;

- creating demand and shaping citizens' needs for digitalisation, primarily through the introduction of large-scale digital transformation projects by the state, in particular on the basis of modern public-private partnership models;

- creating and developing digital infrastructures as a basis for harnessing the benefits of the digital world in everyday life and a platform for achieving economic efficiency in general; 
- developing and enhancing citizens' digital competences to ensure their readiness to take advantage of digital opportunities, as well as to address the associated risks;

- developing of digital entrepreneurship, creation of appropriate (including analogue) infrastructures to support and develop innovative activities, implementation of funding mechanisms, incentive and support mechanisms.

The Concept envisages a shift from a raw material economy that consumes natural resources to high-tech industries and efficient processes through IT and communications. Development of digital infrastructure means broadband Internet availableness throughout Ukraine, digitization of educational processes and stimulation of digital transformations in the education system, medicine, ecology, cashless economy, infrastructure, transport, public safety. The successful experience of Sweden, Korea, Estonia, Ireland and Israel shows that the direct effect of integrated digital economy development is $20 \%$ of GDP (gross domestic product) over five years. It is estimated that by 2021, thanks to the development of the digital economy, Ukraine's GDP will grow at least 5\% [12].

It is possible to determine the level of economy digitization by using different indices. These include the Networked Readiness Index (WEF), the Global Innovation Index (INSEAD, WIPO), the ICT Development Index (ITU), and the Global Competitiveness Index (WEF).

The Global Innovation Index 2019 Report, which compares the innovation activities of 129 countries and economies of the world, recognized Switzerland' as the most innovative country, followed by the United States, the Netherlands and the United Kingdom. Ukraine ranks 47th place in the Global Innovation Index 2019 Report, entering the TOP-3 countries of the lower-middle income economic group.

Compared to 2018, Ukraine has dropped in four lines in this list, though the last few years has steadily moved upwards: in 2016 - from 64th to 56th place, in 2017 - from 56th to 50th place, in 2018 - from 50th to 43rd [13].

Thus, according to the World Economic Forum (WEF) estimation, only 25 countries of the world are ready for the fourth industrial revolution, that is based on digital technologies. These countries already account for $75 \%$ of the value added of the global industrial production.

WEF analysts have attributed Ukraine to the Eurasia Group, which has some industrial base, but the drivers of production development are weak. Ukraine received a rather good rating - 6 (on a ten-point scale) for ability of the Ukrainian producers to produce complex products that is earned its 41 st place in a 100 countries rating. The WEF also well rated a human capital. However, in WEF's view, there are problems in Ukraine with products demand (4.5 points, 58th place) and international trade and investment (5.1 points, 59th place). According to the international experts' estimation, the process of technologies and innovations implementation is extremely bad in Ukraine, with 3.5 points, 74th place. Only $52 \%$ of the population use the Internet (in the UK $-94 \%$, in Russia and the United States - 76\%), while only $1.4 \%$ of Ukrainians have access to the fourth-generation mobile communications, while in Germany and China 4G networks cover about $97 \%$ of the population, and in Poland $100 \%$ [14].
In the digital economy, inexhaustible, accurate, reliable, truthful and timely information is a key resource. The main platform for the digital economy development is a virtual network of boundless Internet. The main principles of the Ukrainian economy digitization at the present stage of its development are [15]:

- accessibility;

- purposefull;

- freedom of the press and information;

- openness and cooperation

- standardization;

- trust and security;

- focusness and comprehensivness.

Digital transformation is a daunting task. Countries that have reached the highest level of digital maturity have had to deal with complex cultural, organizational, and technical issues, and only counting of all these factors have made these transformations successful. In order to become digital leaders today in specific areas of the economy, it is necessary to identify priority digital projects which are implemented by specific organizational teams. Digital teams should focus on three key functional activities, namely, develop a digital strategy, manage digital activity through their national companies, and turn their digital implementation into an operational advantage [16].

One of the main problems with the digital economy development in Ukraine is the lack of a systematic state policy in this area. It is necessary to create a unique model of the digital economy development of Ukraine, which will fully take into account not only the available resources, but also the national and cultural features of Ukraine. The newly created model should not be one that replicates the experience of highly developed countries, but one that "jumps" it. At this stage of development this "digital leap" is important for Ukraine because it will have a positive impact on the country's image in the international arena, on the well-being of the population and on socio-economic development in general.

\section{CONCLUSION}

Therefore, today the digital economy in Ukraine is the basis not only for improving the economy, but also for the effective functioning of public administration and business. The use of information and communication technologies in economic activity is important and necessary, given all the changes that are taking place in Ukrainian society at present times. The widespread use of digital technologies, extensive digital infrastructures are contributing to the economy digitization in Ukraine. In general we can say, that the level of the digital economy development influences on the competitiveness of the state, region, city, village, settlement and growth of well-being of Ukrainian citizens in general. 


\section{REFERENCES}

1 The information society. Wikipedia. Available: https://uk.wikipedia.org.(URL)

2 M.P. Voynarenko, L.V. Skorobogata, "Network tools for the capitalization of information and intellectual potential and innovations," Bulletin of the Khmelnitsky National University, vol. 3, № 3, 2015, pp. 18-24.

3 S.M. Veretyuk, V.V. Pilinskiy, "Determination of priority directions of digital economy development in Ukraine," Scientific notes of the Ukrainian Telecommunication Research Institute, vol. 2(42), 2016, pp. 51-58.

4 S.V. Kolyadenko, "Digital economy: preconditions and stages of formation in Ukraine and in the world," Economics. Finances. Management, vol. 6, 2016, pp. 106-107.

5 Project of Digital Agenda Ukraine, Ukrainian Chamber of Commerce and Industry, official website. Available: https://ucciorguahuploads/files58e78ee3c3922.pdf.(URL)

6 The Concept of a "Digital Economy". Available: http://odec.org.uk/theconcept-of-a-digital-economy. (URL)

7 V.V. Appalkova, "The Concept of Digital Economy Development in the European Union and the Perspectives of Ukraine," Bulletin of the Dnipropetrovsk University, vol. 4, 2015. Available: file: /// C: / Users 1\% D0\% 90\% D0\% B4\% D0\% BC\% D0\% B8\% D0\% BD / Desktop / simp / 52-1-93-1-10 -20160316.pdf.(URL)

8 G.T. Karcheva, T.S. Smovzhenko, V.I. Mishchenko, etc., Eficiency and competitiveness of the banking system of Ukraine (ed. G.T. Karcheva). Kiev: DVNZ“BankingUniversity",2016,276p.

9 Yu. V. Vdovichenko, "Digital technologies as a basis and driving force for the development of the modern global economy," pp. 79-82. Available: http://www.economy.in.ua/pdf/1_2018/17.pdf. (URL)

10 A.E. Gudz, "Modernization of information management of corporate governance based on modern digital technologies," Economy. Management. Business, vol. 3, 2018, pp. 4-12. Available: http://nbuv.gov.ua/UJRN/ecmebi_2018_3_3. (URL)

11 The Concept and Action Plan for the Digital Economy in Ukraine to 2020. Available: http://www.dknii.gov.ua/content/shvaleno-koncepciyu-ta -plan-diy-rozvytku-cyfrovoyi-ekonomiky-v-ukrayini-do2020-roku. (URL)

12 Ministry of Economic Development and Trade of Ukraine, official website. Available: http://me.gov.ual. (URL)

13 Global Innovation Index, official website. Available: https://www.globalinnovationindex.org/gii-2019-report. (URL)

14 O.I. Pizhuk, "Digital transformation of the economy as a basis for shaping its competitiveness," Eastern Europe: Economics, Business and Management, vol. 6 (17), 2018 , pp. 79-83. Available: http://www.easterneurope-ebm.in.ua/journal/17 2018/16. pdf. (URL)

15 N.M. Kraus, O.P. Goloborodko, “ Digital Economy: Trends and Perspectives on the Vanguard Character of Development," Effective Economics, vol. 1, 2018. Available: http://www.economy.nayka.com.ua/pdf/1 2018/8.pdf. (URL)

16 V.P. Kupriyanovsky, A.P. Dobrynin, S.A. Sinyagov, D.E. Namiot, "A holistic model of transformation in the digital economy - how to become digital leaders," International Journal of Open Information Technologies, vol. 5, 2017, pp. 26-33.

\section{AUTHORS PROFILE}

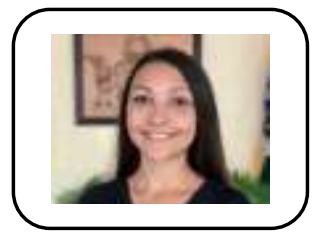

Ludmila Boyko, bachelor, active participant in scientific researches, student asset of the university. Sphere of scientific interests: digital economy, information society.

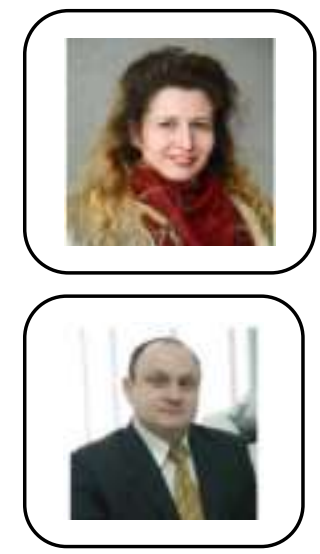

Nataliia Bieliaieva, $\mathrm{PhD}$ in Economics, Associate Professor. Sphere of scientific interests: personnel audit, human resources management, strategic management, modeling of economic processes, digital economy. Has more than 70 scientific and educational works.

Sergiy Bay, Doctor of Economic Sciences, Professor. Sphere of scientific interests: management process optimization organizational development of trade enterprises digital economy. Has more than 300 scientific and educational works.. 